Original research article

\title{
Effect of cognitive training in seniors with dementia
}

\author{
Andrea Botíková ${ }^{1 *}$, Ol'ga Kabátová ${ }^{1}$, Nikol Hošková ${ }^{1}$, Šárka Tomová ${ }^{2}$ \\ ${ }^{1}$ Trnava University, Faculty of Health Sciences and Social Work, Department of Nursing, Trnava, Slovak Republic \\ ${ }^{2}$ Charles University, Second Faculty of Medicine and Motol University Hospital, Institute of Nursing, Praha, Czech Republic
}

\begin{abstract}
Aim: The aim of the research was to demonstrate the positive effect of cognitive training on the state of cognitive functions in seniors with dementia.

Design: Qualitative cross-sectional study.

Methods: A total of 22 seniors who met the criteria (which we specified for listing in the selected sample) participated in the cognitive training. The seniors completed 14 lessons (each lasting 45 minutes) of intensive two-week group cognitive training. The content included exercises for practicing attention and concentration, mnemotechnics and their application in life, and tasks for practicing short-term and long-term memory. All seniors were initially examined with the MoCA-CZ test. After completing the group cognitive training, re-testing and final evaluation were performed. Microsoft Excel was used for statistical processing of the results.

Results: The cognitive training demonstrated a slight increase in the MoCA test score by 1-4 points in 18 cases. In four cases, the score did not change. Thus, after 14 lessons of cognitive training, there was an average increase of the score by 2 points per person. Most of the participants also stated that the cognitive training was beneficial for them and encouraged them to be more active. Moreover, they felt an improvement in cognitive functions after completing it.

Conclusions: Cognitive training has proven to be an effective tool in improving cognitive functions and activity in seniors with mild to moderate dementia.
\end{abstract}

Keywords: Cognitive training; Dementia; Effect; MoCa; Senior

\section{Introduction}

Cognition is a group of mental processes which includes memory, attention, language and decision-making. Its slight deterioration may be an early sign of a disease leading to dementia. Dementia is a severe mental disorder caused by an organic disease or brain damage. The most characteristic indicator of dementia is a cognitive function disorder, which leads to social disability and, at the same time, restricts a person in performing basic daily activities. Therefore, dementia is not only a health problem, but also an economic and social problem (Kalvach et al., 2008). Although dementia is not part of aging, it is most common in elderly persons (Holmerová et al., 2007). According to some findings, the probability of developing dementia in old age is 15-20\% (Ondášiová, 2011).

According to the World Health Organization (WHO), up to $58 \%$ persons with dementia live in the countries with low or middle incomes. In addition, the number of persons suffering from dementia worldwide is currently estimated to be 35.6 million, and this number is estimated to increase to 65.7 million by 2030 , and to 115.4 million by 2050 (WHO, 2017).

The transition phase between cognitive changes in physiological aging and those in early dementia is mild cognitive im- pairment - MCI (Janoutová et al., 2018). Cognitive training is a very promising non-pharmacological alternative to slowing down the progression of MCI to Alzheimer's disease (Zhang et al., 2019). Cognitive training represents a lectured activity focused on cognitive functions, such as memory and attention, or executive functions. Cognitive training may also result in the improvement of metacognition, cognitive ability and self-efficacy (Štěpánková and Steinová, 2009). It is comprehensively oriented and directed towards the strengthening of concentration, recovery of vocabulary, support of associative and logical thinking, imagination and creativity. It is based on a number of methods and techniques which include informal activities, such as a conversation in a foreign language, chess, crossword puzzles, sudoku, and special techniques (Janečková et al., 2004). Studies show that game-like cognitive training may effectively improve cognitive functions in elderly persons (Hakun et al., 2015; Lampit et al., 2014) and even reverse age-related decline in cognitive capacity.

The goal of the research was to demonstrate the positive effect of cognitive training on the state of cognitive functions in seniors with dementia. An increase in the score or a positive score stagnation in the MoCA test was considered a success. The partial goal was to find out the subjective opinion of seniors on cognitive training.

\footnotetext{
* Corresponding author: Andrea Botíková, Trnava University, Faculty of Health Sciences and Social Work, Department of Nursing, Univerzitné nám. 1, 91743 Trnava, Slovak Republic; e-mail: andrea.botikova@truni.sk http://doi.org/10.32725/kont.2020.032 


\section{Materials and methods}

The design of a qualitative cross-sectional study was selected for this research. The research was conducted in patients of the Geriatric and Long-Term Care Department (GaNP) of Thomayer Hospital, after it had been approved by the medical facility, in July and August 2016.

We assessed the effect of cognitive training in patients who met our criteria: age from 65 to 85 , MoCA test score of 26-13 points, mild to moderate dementia diagnosed by a geriatrist, ability to communicate and understand communication, corrected vision and hearing, which allows them to participate in the cognitive training, absence of serious mental disorders and a patient's consent to being included in the research. In order to be able to objectively prove the effect of cognitive training, we intentionally included only seniors with mild to moderate dementia in the sample group. Diagnosed severe dementia was an exclusion criterion, because the effect of cognitive training in these seniors is without a significant observable effect (as the screening tools are no table to detect it). 14 seniors were excluded for not meeting the selection criteria. A total of 22 seniors, 10 men and 12 women at the age of 75.6 on average, were included in the research. All the seniors were diagnosed with mild dementia. The participants completed 14 lessons (each lasting 45 minutes) of intensive two-week group cognitive training. The content included exercises for practicing attention and concentration, mnemotechnics and their application in life, and tasks for practicing short-term and long-term memory. All the seniors were initially examined with the MoCA-CZ test, which is one of the initial examinations when admitting patients to GaNP. After completing the group cognitive training, a re-testing with the MoCA test was performed, as well as a final evaluation, which included questions concerning opinions about one's own memory after the training, interest in further trainings, as well as one's expression of the cognitive training benefits. A 2012 MoCA-CZ1 test version, which can be used freely for clinical and educational purposes, was used for testing. Finally, we recorded the results in tables used for statistical processing and added a theoretical description. Microsoft Excel was used for statistical processing of the results.

\section{Results}

The effect of cognitive training in seniors with mild dementia expressed in the MoCA-CZ test score is shown in Table 1. In 18 cases, there was a slight increase of 1-4 points in the MoCA test score. In four cases, the score did not change. There was an average increase in the score by 1.7 points for men and by 2.3 points for women. All in all, we can say that after completing 14 lessons of cognitive training, there was an average increase in the score by 2 points.

Table 1. Results of MoCA test before and after completion of cognitive training

\begin{tabular}{|c|c|c|c|c|c|c|c|c|c|c|c|}
\hline & & & Effect & & & & & & Effec & & \\
\hline Men & Before & After & $(+)$ & $(-)$ & $(=)$ & Women & Before & After & $(+)$ & $(-)$ & $(=)$ \\
\hline M1 & 17 & 20 & 3 & & & W1 & 14 & 16 & 2 & & \\
\hline M2 & 19 & 20 & 1 & & & W2 & 19 & 21 & 2 & & \\
\hline M3 & 21 & 22 & 1 & & & W3 & 17 & 19 & 2 & & \\
\hline M4 & 16 & 18 & 2 & & & W4 & 15 & 19 & 4 & & \\
\hline M5 & 17 & 20 & 3 & & & W5 & 15 & 18 & 3 & & \\
\hline M6 & 20 & 21 & 1 & & & W6 & 20 & 20 & 0 & & 0 \\
\hline M7 & 15 & 15 & 0 & & 0 & W7 & 18 & 18 & 0 & & 0 \\
\hline M8 & 15 & 18 & 3 & & & W8 & 17 & 21 & 4 & & \\
\hline M9 & 14 & 14 & 0 & & 0 & W9 & 16 & 19 & 3 & & \\
\hline \multirow[t]{3}{*}{ M10 } & 16 & 19 & 3 & & & W10 & 19 & 22 & 3 & & \\
\hline & & & & & & W11 & 19 & 20 & 1 & & \\
\hline & & & & & & W12 & 16 & 19 & 3 & & \\
\hline Average in men & & & 1.7 & & & \multicolumn{2}{|c|}{ Average in women } & & 2.3 & & \\
\hline Overall average & & & & & & & & & & & 2 \\
\hline
\end{tabular}

Furthermore, we also investigated subjective opinions of the seniors on the cognitive training. We prepared a short questionnaire to assess this partial goal, in which we wanted to find out how the seniors evaluate the benefits of the cognitive training for themselves, whether they observe any improvement of their memory, and whether their participation in the group is an inspiration for them to continue in this or a similar activity.

Table 2 shows the seniors' responses regarding the cognitive training benefits. None of the participants responded "of little benefit" and "unbeneficial". One man responded "neither beneficial nor unbeneficial", which is $5 \%$ of the total number of respondents. Three men (30\%) and five women (42\%) evaluated the training as "beneficial". The option "very beneficial" was chosen by $59 \%$ of the total number of the respondents.

In the next question (Table 3), we asked whether the seniors felt any self-improvement. None of the respondents chose the answer "no". One man and one woman chose "I can't say" with an explanation they would rather let their relatives assess that. Two men and one woman chose "it's the same", which represents $14 \%$ of the total number of the cognitive training participants. 7 seniors noticed a small improvement (32\%). 10 seniors, 4 men and 6 women (45\%), felt a great improvement. 
Table 2. Benefits of cognitive training for seniors

\begin{tabular}{lccccccc} 
Number & Response & Number of M & $\%$ & Number of W & $\%$ & Number of M, W & $\%$ \\
\hline 1 & Very beneficial & 6 & 60 & 7 & 58 & 13 & 59 \\
2 & Beneficial & 3 & 30 & 5 & 42 & 36 & 0 \\
3 & Neither beneficial nor unbeneficial & 1 & 10 & 0 & 0 & 0 & 0 \\
4 & Of little benefit & 0 & 0 & 0 & 0 & 0 \\
5 & Unbeneficial & 0 & 0 & 0 & $\mathbf{1 0 0}$ & $\mathbf{2 2}$ & $\mathbf{1 0 0}$ \\
\hline
\end{tabular}

Table 3. Feeling of improvement

\begin{tabular}{|c|c|c|c|c|c|c|c|}
\hline Number & Response & Number of $\mathrm{M}$ & $\%$ & Number of W & $\%$ & Number of $\mathrm{M}, \mathrm{W}$ & $\%$ \\
\hline 1 & Great improvement & 4 & 40 & 6 & 50 & 10 & 45 \\
\hline 2 & Small improvement & 3 & 30 & 4 & 33 & 7 & 32 \\
\hline 3 & It's the same & 2 & 20 & 1 & 8 & 3 & 14 \\
\hline 4 & I can't say & 1 & 10 & 1 & 8 & 2 & 9 \\
\hline \multirow[t]{2}{*}{5} & No improvement & 0 & 0 & 0 & 0 & 0 & 0 \\
\hline & Total & 10 & 100 & 12 & 100 & 22 & 100 \\
\hline
\end{tabular}

We asked the last question to find out whether the cognitive training inspired the seniors to be more active (Table 4). 17 seniors $(85 \%)$ chose "certainly yes" and "yes". Two of the seniors chose "yes and no". The same applies for "I haven't decided yet". Their choice is based on the fact that after hospitalization they will be taken to a senior facility. Although these activities are possible, they are paid and the seniors are afraid they will lack finances. In addition, the seniors stated they do not know whether these activities are not too far away and whether there will be any staff to take them to cognitive training lessons. One man and one woman chose "yes and no". One man picked "I haven't decided yet".

Table 4. Inspiration to activity

\begin{tabular}{lccccccc} 
Number & Response & Number of M & $\%$ & Number of W & $\%$ & Number of M, W & $\%$ \\
\hline 1 & Certainly yes & 5 & 50 & 6 & 60 & 11 \\
2 & Yes & 3 & 30 & 3 & 30 & 6 \\
3 & Yes and no & 1 & 10 & 1 & 10 & 30 & 2 \\
4 & I haven't decided yet & 1 & 10 & 0 & 0 & 1 & 0 \\
5 & No & 0 & 0 & 0 & 0 & 0 \\
\hline
\end{tabular}

\section{Discussion}

Dementia is currently becoming the main health and social problem in the care of seniors and is an economic challenge worldwide. Its occurrence is significantly influenced by the aging of the population (Prince et al., 2015). Dementia is a condition characterised by decreased cognitive abilities, progressive deterioration of personal capabilities and independence. It is a clinical syndrome in which cognitive damage, loss of communicative and manual skills and/or neuropsychiatric problems cause a distinctive decline in comparison to previous levels and a decrease in ability to perform ordinary everyday activities (McKhann et al., 2011).

The symptoms of a neurodegenerative disease can be categorised into three main groups: cognitive, neuropsychiatric and neurological. A cognitive decline usually includes memory, attention and executive functions. There are difficulties in finding words and communicating, problems with focusing, reasoning, planning and processing complex tasks (Peña-Casanova et al., 2012). In clinical practice, as well as in research, cognition is considered a key factor observed in patients with dementia (Sheehan, 2012).

The treatment of dementia focuses on the symptoms of the disease and is governed by its stages. The main goals of the treatment include the preservation of the existing functional and cognitive abilities, minimizing behavioural disorders and a slow progress of the disease (Sadowsky and Galwin, 2012). The pharmacological influence is aimed at supporting and maintaining cognitive functions with drugs called cognitives, as well as the correction of non-cognitive symptoms of dementia (treatment of depression with antidepressants, treatment of behavioural disorders with antipsychotics or acetylcholinesterase inhibitors, treatment of sleeping disorders with hypnotics, sedative antidepressants or antipsychotics are the most common in practice). Improving the level of functioning of a patient with dementia in everyday life is not the only therapeutic success. In addition, there is also slowing down the 
progress of the disease, as well as postponing its severe stages (Pidrman, 2005).

In addition to pharmacological treatment, several non-pharmacological therapies are currently being proposed for patients with dementia, including proper nutrition, nutritional supplements, physical activity, psychosocial intervention, reminiscence, music therapy, practicing daily activities and cognition-focused approaches (Olazarán et al., 2010). The non-pharmacological influence is as important as the pharmacological one. It is a less expensive solution, but a very effective one from the point of view of maintaining self-efficacy, improving patient's functioning and his/her self-assessment and quality of life. Both medical and non-medical staff is involved in the non-pharmacological intervention. The most common members of the team are doctors, nurses, physiotherapists, therapeutic pedagogists, social workers, nutritionists, psychologists, family members and care takers and, last but not least, the patient himself/herself. Nurses who provide non-pharmacological treatment both at home and in institutional facilities are very important team members. Nurses perform individual interventions independently, in cooperation with a doctor and based on his/her ordination - in accordance with the current legislation (Decree of the Ministry of Health of the Slovak Republic No. 95/2018 Coll).

These interventions mainly include the education of seniors and their families with an emphasis on self-efficacy and daily activities, nursing rehabilitation, prevention of immobility disorders, physical therapy, medical nutrition, dietotherapy, phytotherapy, hydration, mental activation. Common methods include basal stimulation, reminiscence therapy and validation, cognitive rehabilitation, which, however, require completing special courses and certification (Zrubáková et al., 2018). One of the most used dementia treatment modalities is cognitive training, which is based on the training of cognitive functions using quizzes, games, crossword puzzles, work with calendars, newspapers, magazines, etc. (Lužný, 2011).

The most common finding which occurs in cognitive training related to dementia is a slight improvement of cognitive abilities in persons with dementia measured with the MMSE (Mini-Mental State Examination) or MoCa test immediately after the training period (De Luca et al., 2016; Huntley et al., 2017; Trebbastoni et al., 2018). In our case, after completing 14 cognitive training lessons, there was an increase in the $\mathrm{MoCa}$ test by 2 points on average, while in only four patients out of 22 cases did the score before and after the training not change at all. In his monitoring of a sample of 62 female patients with dementia (2011), Lužný was not able to demonstrate a statistically significant difference in the improvement of cognitive functions assessed using the MMSE range and Clock drawing test during the monitored period. As a reason, the author states a very short period of monitoring, in which no potential improvement in the level of cognitive functions can be detected (the average length of hospitalization was 34.6 days).

It would be appropriate to assess cognitive functions after a longer time period of 3-6 months (Jirák and Borzová, 2006). However, Lužný (2011) points out that the level of cognitive functions in all cases has stabilized, which can be considered a therapeutic success given the current state of knowledge. Most of the studies evaluating the effectiveness of non-pharmacological effects on cognitive functions in patients with mild to moderate dementia report the benefits of involving these non-pharmacological interventions in the comprehensive de- mentia treatment management (Olazarán et al., 2010). Thus, non-pharmacological therapy is an important part of taking care of a senior with dementia, especially abroad. In Slovakia, however, the situation is different.

Based on the data from a clinical research, Zrubáková et al. (2018) found that individual non-pharmacological procedures cannot be performed adequately in after-treatment departments, hospitals and facilities for long-term patients and senior facilities due to an insufficient number of nurses and absence of physiotherapists (as well as other experts). The mutual coordination in the cooperation of medical and social workers, therapeutic pedagogists and psychologists also stagnates. Furthermore, they found that non-pharmacological treatment applied in health and social facilities is primarily focused on activating seniors, nutrition and hydration. The negative fact was that nurses in institutional facilities do not use cognitive rehabilitation, reminiscence therapy and validation when working with patients with mild cognitive disorder and dementia, even though these are the recommended methods in the care of geriatric patients.

As for the subjective evaluation of cognitive training, Lužný's study (2011) produced similar results to ours; most of the patients evaluated the psychotherapeutic activities they participated in during their hospitalization positively. The patients mainly appreciated the friendly and understanding approach and reported a subjective improvement of their condition. In addition, they appreciated the group form of activities at the department, increased self-confidence and positively evaluated the evocation of pleasant memories, gaining new information and friends, as well as strengthening their self-esteem. The experience of the staff with the involvement of the clients with dementia in the psychotherapeutic activities was also positive. There was an activation of the clients on several levels, dynamization of the atmosphere at the inpatient department, and improvement in the daily regime structure of the hospitalized patients.

\section{Limitations}

We perceive the limitations of our research to be a small research sample and an unevenly distributed group of respondents. A relatively short period of cognitive training and monitoring of its participants may also be considered a limitation.

\section{Conclusions}

Taking care of a senior with dementia is demanding. It requires an individual, interdisciplinary approach and a combination of several treatment methods. For nurses working with seniors with dementia, we recommend using non-pharmacological methods in the treatment and care of these fragile patients with a focus on cognitive function training. As our study showed, it is effective in improving cognitive functions, as well as the overall activation of seniors. Particular attention should be paid to seniors with a mild cognitive deficit, who are expected to experience a greater improvement in cognition and everyday activities.

\section{Ethical aspects and conflict of interests}

The authors declare no conflicts of interests and that the ethical aspects of research were respected in its preparation. 


\section{Efektivita kognitívneho tréningu u seniorov s demenciou}

\section{Súhrn}

Ciel: Ciel'om výskumu bolo preukázat' pozitívny efekt kognitívneho tréningu na stav kognitívnych funkcií u seniorov s demenciou. Dizajn: Kvalitatívna prierezová štúdia.

Metodika: Kognitívneho tréningu sa zúčastnilo celkom 22 seniorov, ktorí spíňali nami stanovené kritéria zaradenia do výberového súboru. Seniori absolvovali 14 lekcii intenzívneho dvojtýždňového skupinového kognitívneho tréningu v trvaní 45 minút.

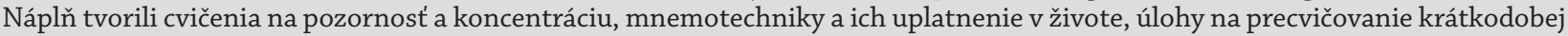
a dlhodobej pamäti. Všetci seniori boli na začiatku vyšetrení testom MoCA-CZ. Po skončení skupinového kognitívneho tréningu prebehlo re-testovanie a záverečné hodnotenie. Pre štatistické spracovanie výsledkov bol použitý program Microsoft Excel. Výsledky: Kognitívny tréning preukázal v 18 prípadoch mierne navýšenie bodov v MoCA teste v rozsahu 1-4 bodov. V štyroch prípadoch sa stav bodov nezmenil. Po skončení 14 lekcií kognitívneho tréningu teda došlo u seniorov k navýšeniu v priemere o 2 body. Väčšina účastníkov tiež uviedla, že kognitívny tréning bol pre nich prínosný, povzbudil ich k d'alšej aktivite a subjektívne pocitovali po jeho absolvovaní zlepšenie v oblasti kognitívnych funkcií.

Záver: Kognitívny tréning sa preukázal ako efektívny nástroj pri zlepšovaní kognitívnych funkcií a aktivity seniorov s miernou až stredne tažkou demenciou.

Kl'účové slová: demencia; efekt; kognitívny tréning; MoCa; senior

\section{References}

1. De Luca, R, Bramanti A, De Cola MC, Leonardi S, Torrisi M, Aragona B, Calabro RS (2016). Cognitive training for patients with dementia living in a sicilian nursing home: a novelwebbased approach. Neurol Sci 37(10): 1685-1691. DOI: 10.1007/ s10072-016-2659-x.

2. Decree of the Ministry of Health of the Slovak Republic No. 95/2018 Coll. [online] [cit. 2020-04-14]. Available from: https://www.slov-lex.sk/pravne-predpisy/SK/ZZ/2018/95/ vyhlasene_znenie.html

3. Hakun JG, Zhu ZD, Johnson NF, Gold BT (2015). Evidence for reduced efficiency and successful compensation in older adults during task switching. Cortex 64: 352-362. DOI: 10.1016/j. cortex.2014.12.006.

4. Holmerová I, Jurašková B, Zikmundová K, et al. (2007). Vybrané kapitoly z gerontológie. Praha: EV Public Relations, spol. s r. o., 143 p.

5. Huntley JD, Hampshire A, Bor D, Owen A, Howard RJ (2017). Adaptive Works memory strategy training in early Alzheimer's disease: Randomised controlled trial. The British Journal of Psychiatry 210(1): 61-66. DOI: 10.1192/bjp.bp.116.182048.

6. Janečková H, Kalvach Z, Holmerová I (2004). Programování aktivit, motivování a akceptování kognitivní rehabilitace. In: Kalvach Z, Zadák Z, Jirák R, et al. Geriatrie a gerontologie. Praha: Grada Publishing, 864 p.

7. Janoutová J, Ambroz P, Kovalová M, Machaczka O, Němček K, Zatloukalová A, et al. (2018). Epidemiologie mírné kognitivní poruchy. Cesk Slov Neurol N 81(3): 284-289. DOI: 10.14735/ amcsnn2018284.

8. Jirák R, Borzová C (2006). Demence. In: Raboch J, et al. Psychiatrie. Doporučené postupy psychiatrické péče II. Praha: Infopharm, $204 \mathrm{p}$.

9. Kalvach Z, Zadák Z, Jirák R, Zavázalová H, Holmerová I, Weber P, et al. (2008). Geriatrické syndromy a geriatrický pacient. Praha: Grada, 336 p.

10. Lampit A, Hallock H, Valenzuela M (2014). Computerized cognitive training in cognitively healthy older adults: a systematic review and meta-analysis of effect modifiers. PLoS Med 11:e1001756. DOI: 10.1371/journal.pmed.1001756.

11. Lužný J (2011). Nefarmakologické ovlivnění kognitivních funkcí u klientů s demencí. Ošetřovatelství a porodní asistence 2(4/2011): 312-318.

12. McKhann GM, Knopman DS, Chertkow H, Hyman BT, Jack CR, Jr., Kawas CH, et al. (2011). The diagnosis of dementia due to Alzheimer's disease: recommendations from the National Institute on Aging-Alzheimer's Association workgroups on diagnostic guidelines for Alzheimer's disease. Alzheimers Dement 7(3): 263-269. DOI: 10.1016/j.jalz.2011.03.005.

13. Olazarán J, Reisberg B, Clare L, Cruz I, Pena-Casanova J, del Ser T, et al. (2010). Nonpharmacological therapies in Alzheimer's disease: A systematic review of efficacy. Dementia and Geriatric Cognitive Disorders 30: 161-178. DOI: 10.1159/000316119.

14. Ondášiová M. (2011). Kognitívne poruchy vo vyššom veku. Bratislava: Herba, 156 p.

15. Peña-Casanova J, Sánchez-Benavides G, de Sola S, ManeroBorrás RM, Casals-Coll M (2012). Neuropsychology of Alzheimer's Disease. Archives of Medical Research 43(8): 686-693. DOI: 10.1016/j.arcmed.2012.08.015.

16. Pidrman, V (2005). Kognitiva a další léky pro léčbu demencí a kognitivních poruch. In: Bouček J, Pidrman V. Psychofarmaka v medicíně. Praha: Grada Publishing, 304 p.

17. Prince MJ, Wimo A, Guerchet MM, Ali GC, Wu, YT, Prina M (2015). World Alzheimer Report 2015 - The Global Impact of Dementia. London: Alzheimer's Disease International.

18. Sadowsky CH, Galvin JE (2012). Guidelines for the Management of Cognitive and Behavioral Problems in Dementia. J Am Board Fam Med 25(3): 350-366. DOI: 10.3122/jabfm.2012.03.100183.

19. Sheehan B (2012). Assessment scales in dementia. Ther Ad Neurol Disord 5(6): 349-358. DOI: $10.1177 / 1756285612455733$.

20. Štěpánková H, Steinová D (2009). Trénování paměti. Praha: Psychiatrické centrum.

21. Trebbastoni A, Imbriano L, Podda L, Rendace L, Sacchetti ML, Campanelli A, et al. (2018). Cognitive Training in Patients with Alzheimer's Disease: Findings of a 12-month Randomized Controlled Trial. Curr Alzheimer Res 2018.15(5): 452-461. DOI: $10.2174 / 1567205014666171113105044$.

22. World Health Organization (2017). Dementia. [online] [cit. 2019-05-09]. Available from: https://www.who.int/ publications-detail/isupport-for-dementia

23. Zhang K, Wang J, Peng G, Liu P, He F, Zhu Z, et al. (2019). Effect of cognitive training on episodic memory retrieval in amnestic mild cognitive impairment patients: study protocol for a clinical randomized controlled trial. Trials 20(1): 26. DOI: 10.1186/ s13063-018-3143-0.

24. Zrubáková K, Novysedláková $M$, Magerčiaková M, Šupínová $M$ (2018). Využitie nefarmakologickej liečby u seniorov v domácej a ústavnej starostlivosti. Ošetřovatelské perspektivy 1(2): 55-66. DOI: 10.25142/osp.2018.018. 